\title{
KONSELING KELOMPOK REALITA UNTUK MENINGKATKAN KEDISIPLINAN BELAJAR SISWA MADRASAH IBTIDAIYAH, EFEKTIFKAH?
}

\author{
Faralia Nadhifa ${ }^{1}$, Bakhrudin All Habsy ${ }^{2}$, \& Tadjoer Ridjal ${ }^{3}$ \\ e-mail: faralian2@gmail.com ${ }^{1}$, bakhrudin_bk@yahoo.com ${ }^{2}$, \\ tadjoer.bdr@undar.com ${ }^{3}$ \\ Bimbingan dan Konseling, Madrasah Ibtidaiyah Semesta Kedungmaling ${ }^{1}$ \\ Bimbingan dan Konseling, Universitas Darul Ulum Jombang ${ }^{2}$ \\ Program Pascasarjana, Universitas Darul Ulum Jombang ${ }^{3}$ \\ Jalan Kedungmaling, Kecamatan Sooko, Kabupaten Mojokerto, Jawa Timur ${ }^{1}$ \\ Jalan Gus Dur No.29A, Mojongapitindah, Mojongapit, Kec. Jombang, \\ Kabupaten Jombang, Jawa Timur 614192,3
}

\begin{abstract}
Abstrak: Penelitian ini bertujuan untuk mengetahui keefektifan konseling kelompok realita dalam meningkatkan kedisipilinan siswa di sebuah Madrasah Ibtidaiyah. Penelitian ini, menggunakan rancangan eksperimen dengan desain pretest dan posttest control group. Penelitian dilaksanakan selama 6 bulan dengan menggunakan pendekatan konseling kelompok realita dengan teknik metafora dan diskusi kualitas. Data dianalisis menggunakan uji t-test. Berdasarkan hasil penelitian ditemukan bahwa konseling kelompok realita efektif untuk meningkatkan kedisiplinan belajar siswa pada Madrasah Ibtidaiyah yang dijadikan sampel penelitian. Saran dan rekomendasi dari hasil penelitian ini antara lain: 1) Guru Bimbingan dan Konseling dapat menerapkan layanan konseling kelompok ralita sebagai alternatif untuk meningkatkan kedisiplinan siswa, 2) Peneliti selanjutnya dapat menggunakan teknik lain yang relevan untuk menguji keefektifan konseling kelompok realita.
\end{abstract}

Kata-kata kunci: kedisiplinan siswa, konseling kelompok realita

\section{THE EFFECTIVITY OF REALITY GROUP COUNSELING IN IMPROVING ISLAMIC PRIMARY SCHOOL PUPILS' LEARNING DISCIPLINE}

\begin{abstract}
This study aims to determine the effectiveness of reality group counseling in increasing pupils' discipline in an islamic primary school. This study used an experimental design with a pretest and posttest control group design. The study was conducted for 6 months using a reality group counseling approach with metaphorical techniques and quality discussion. Data were analyzed using $t$-test. Based on the results of the study it was found that reality group counseling was effective to improve pupils' learning discipline in the islamic primary school which was used as the research sample. Suggestions and recommendations from the results of this study include: 1) Guidance and Counseling teachers can apply the ralita group counseling service as an alternative to improving pupils' discipline, 2) The next researcher can use other relevant techniques to test the effectiveness of reality group counseling.
\end{abstract}

Keywords: pupil's learning discipline, reality group counseling 


\section{PENDAHULUAN}

Madrasah Ibtidaiyah yang selanjutnya disebut MI merupakan jenjang pendidikan formal paling dasar di Indonesia yang ditempuh dalam waktu 6 tahun, mulai dari kelas 1 sampai kelas 6, dengan pengelolaannya dilakukan oleh kementrian agama (Islam, 2001). Karakteristik siswa MI adalah mereka yang berusia sekitar 6-13 dengan tahap perkembangan masa anakanak dan memasuki masa pra remaja awal.

Menurut Habsy (2017) selama masa perkembangan pra remaja siswa MI kelas VI mereka mulai menilai diri mereka sendiri dengan tolak ukur orang lain. Masa perkembangan pra remaja lebih mudah menggunakan perbandingan sosial (social comparison) terutama untuk norma-norma sosial dan kesesuaian jenis-jenis tingkah laku tertentu. Pada saat anak-anak tumbuh semakin lanjut, mereka cenderung menggunakan perbandingan sosial untuk mengevaluasi dan menilai kemampuan-kemampuan mereka sendiri. Sebagai akibat dari perubahan struktur fisik dan kognitif mereka. Terjadi perubahanperubahan yang berarti dalam kehidupan sosial dan emosional mereka. Salah satu tanda mulai munculnya perkembangan identitas remaja adalah reflektivitas yaitu kecenderungan untuk berpikir tentang apa yang sedang berkecamuk dalam benak mereka sendiri dan mengkaji diri sendiri (Havighurst dalam Manning, 2002).

Problematika yang terjadi pada individu pra remaja pada siswa kelas VI MI adalah tentang kedisiplinan belajar. Menurut Isnaini (2014) kedisiplinan belajar adalah predis posisi (kecenderungan) suatu sikap mental untuk mematuhi aturan, tata tertib, dan sekaligus mengendalikan diri, menyesuaikan diri terhadap aturan-aturan yang berasal dari luar sekalipun yang mengekang dan menunjukkan kesadaran akan tanggung jawab terhadap tugas dan kewajiban.

Berdasarkan hasil penelitian Widodo (2013) diskripsi perilaku tidak disiplin siswa diantaranya perilaku membolos, terlambat masuk sekolah, rebut di kelas, mengobrol saat guru sedang menjelaskan pelajaran, tidak mengenakan atribut sekolah secara lengkap, dan menyontek. Lebih lanjut Harlinawati (2016) menegaskan salah satu faktor penyebab utama munculnya perilaku tidak disiplin adalah tidak adanya kesadaran akan tanggung jawab sebagai siswa serta seringnya siswa melanggar peraturan yang ditetapkan sekolah. Perilaku tidak disiplin belajar pada siswa apabila dibiarkan akan membawa dampak yang kurang menguntungkan terhadap prestasi belajar maupun sikap mental para siswa.

Menurut Gunawan (2016) ketidakdisiplinan akan mengganggu pembelajaran sehingga berpengaruh terhadap kurang berkembangnya prestasi belajar siswa. Bahkan pada sebuah kasus ketidaknaikan kelas yang dialami siswa, faktor penyebab yang paling mempengaruhi adalah rendahnya kedisiplinan belajar siswa. Menurut Arisana \& Ismani (2012) menegaskan factor-faktor yang mempengaruhi kedisiplinan antara lain: (1) Pola asuh dan kontrol yang dilakukan oleh orang tua, (2) Pemahaman tentang diri dan motivasi, (3) Hubungan sosial dan pengaruhnya terhadap individu.

Berdasarkan hasil studi pendahuluan yang dilakukan peneliti di Madrasah Ibtidaiyah Semesta kedungmaling pada tanggal 15-17 Maret 2018 melalui kegiatan wawancara dengan guru BK (Bimbingan Konseling) yang diperkuat dengan adanya catatan buku pelanggaran dan laporan dari guru mata pelajaran, bahwasanya hampir $50 \%$ dari jumlah seluruh siswa \pm 300 siswa mengalami disiplin belajar yang rendah. Hal itu ditunjukkan oleh perilaku yang kurang bertanggung jawab pada siswa seperti masih terdapat beberapa siswa yang tidak mengerjakan pekerjaan rumah, banyak siswa yang gaduh di dalam kelas, sering tidak masuk sekolah, siswa sering tidak mencatat, siswa sering menjahili temannya sampai menangis, siswa lebih senang berbicara dengan teman-temannya dari pada mencoba mengerjakan tugas, tidak mendengarkan saat guru menerangkan dan masih banyak lagi perilaku tidak disiplin belajar yang dilakukan siswa disekolah.

Berdasarkan hasil wawancara dengan guru BK di Madrasah Ibtidaiyah Semesta kedungmaling memiliki kedisiplinan belajar yang rendah dibandingkan dengan kelas yang lainnya sehingga guru BK menyarankan untuk dijadikan sebagai subjek penelitian. Selain itu penulis juga melakukan wawancara dengan beberapa guru mata pelajaran yang mengampu kelas $6 \mathrm{~B}$, dengan hasil uraian sebagai berikut: terdapat siswa yang terlambat masuk ke kelas, beberapa siswa ditegur oleh guru karena ramai atau bercakap-cakap dengan siswa lain pada saat guru menerangkan, siswa tidak membawa buku mata pelajaran, siswa tidak mengerjakan pekerjaan rumah, siswa sering menjahili teman sampai menangis dan siswa sering berkelahi dengan teman.

Kedisiplinan belajar dalam penelitian ini adalah perbuatan orang-orang mematuhi aturan belajar atau metode agar orang-orang mematuhi aturan dalam pengajaran untuk melakukannya dan menghukum jika mereka tidak mematuhi aturan belajar. Kedisiplinan 
belajar terwujud dalam suatu perintah dan suatu keadaan yang dikendalikan dalam pengajaran, terutama di dalam suatu kelas anak-anak sekolah. Dalam penelitian ini untuk mengukur kedisiplinan belajar dengan menggunakan angket kedisiplinan sosial berdasarkan teori Hurrlock (1978) yang terdiri atas indikator-indikator yaitu (1) patuh dan taat terhadap tata tertib belajar di sekolah, (2) persiapan belajar, (3) perhatian terhadap kegiatan pembelajaran, (4) dan menyelesaikan tugas pada waktunya.

Berdasarkan kajian penelitian terdahulu dapat ditafsirkan bahwa, perilaku tidak disiplin yang dilakukan siswa, apabila tidak segera mendapat penanganan tentunya akan berpengaruh negatif pada kepribadian siswa. Konselor sekolah memiliki tanggung jawab lebih besar untuk menangani problematika-problematika siswa di sekolah (Habsy.,dkk 2017). Hal itu sesuai dengan tujuan umum bimbingan dan konseling menurut Habsy (2017) yaitu membantu siswa agar dapat mencapai perkembangan secara optimal sesuai dengan bakat, kemampuan, minat dan nilai-nilai, serta terpecahnya masalahmasalah yang dihadapi siswa. Untuk membantu siswa meningkatkan disiplin belajarnya. Salah satu layanan Bimbingan dan konseling yang diterapkan untuk menangani permasalahan kedisiplinan adalah layanan Konseling Kelompok.

Menurut Suharnan (dalam Rosidah, 2016) konseling kelompok adalah salah satu upaya bantuan kepada peserta didik dalam suasana kelompok yang bersifat pencegahan dan penyembuhan dan diarahkan kepada pemberian kemudahan dalam rangka pengembangan dan pertumbuhannya. Pelaksanaan konseling kelompok untuk meningkatkan disiplin belajar siswa dilaksanakan dengan menggunakan pendekatan realita.

Menurut Rahman (2015) Konseling realita merupakan konseling yang berfokus pada perilaku sekarang untuk mencapai masa depan bukan pada perilaku yang terdahulu. Hal itu tentunya akan membantu konseli dalam meningkatkan disiplin belajarnya dengan menekankan pada tanggung jawab konseli sebagai siswa. Beberapa hasil penelitian telah permasalahan dalam seting pendidikan maupun dalam seting lainnya. Penelitian yang dilakukan oleh Kim (dalam Hardiansyah, 2013) membuktikan bahwa konseling kelompok Realita dapat meningkatkan harga diri mahasiswa yang mengalami kecanduan internet. Penelitian lain yang dilakukan oleh Ismail (dalam Rahman, 2015) juga menunjukkan bahwa Konseling Realita, Konseling Kelompok Client Centered, dan Model Egan dapat meningkatkan harga diri dan keterampilan menghadapi masalah konseli yang berasal dari berbagai latar belakang.

Konseling kelompok realita dalam penelitian ini adalah salah satu upaya bantuan kepada peserta didik dalam suasana kelompok yang bersifat pencegahan dan penyembuhan dan diarahkan kepada pemberian kemudahan dalam rangka perkembangan dan pertumbuhannya yang memfokuskan pada tingkah laku sekarang. Tahap-tahap konseling kelompok realita memiliki delapan tahap yaitu (1) konselor menunjukkan keterlibatan dengan konseli (Be Friend), (2) fokus pada perilaku sekarang, (3) mengeksplorasi total behavior konseli, (4) konseli menilai diri sendiri atau melakukan evaluasi, (5) merencanakan tindakan bertanggung jawab, (6) membuat komitmen, (7) tidak menerima permintaan maaf atau alasan konseli, dan (8) tindak lanjut. Secara visual mekanisme konseling divisualisasikan pada gambar berikut:

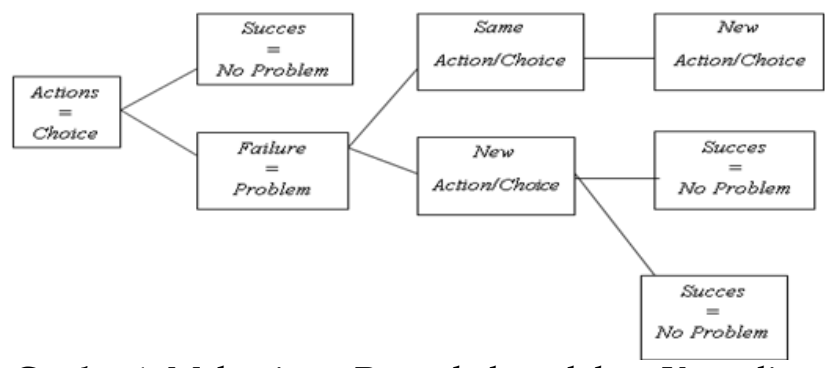

Gambar 1. Mekanisme Pengubahan dalam Konseling Realita

Sebagaimana telah di deskripsikan oleh penulis pada latar belakang permasalahan, maka rumusan masalah dalam penelitian ini adalah apakah konseling kelompok realita dapat meningkatkan kedisplinan belajar siswa MI secara efektif?

\section{METODE PENELITIAN}

\section{Desain Penelitian}

Desain atau rancangan penelitian merupakan suatu proses yang diperlukan dalam perencanaan dan pelaksanaan sebuah penelitian (Habsy, 2017c). Pada penelitian kali ini metode penelitian yang digunakan oleh peneliti adalah dengan pendekatan kuantitatif. Penelitian ini memakai jenis True Eksperimental Design (eksperimen murni) dengan rancangan eksperimen yang menggunakan desain penelitian Eksperimen Pre-test and Post-test Control Group Design. Desain penelitian ini, lebih jelasnya dapat dilihat pada gambar di bawah ini:

\begin{tabular}{llll} 
R1 & O1 & $X$ & 02 \\
\hline R2 & O3 & & O4
\end{tabular}

Gambar 2. Rancangan Penelitian

(Sumber: Habsy, 2018) 
Keterangan:

R1 : Penempatan kelompok secara acak pada kelompok eksperimen

O1 : Pre-test sebelum subjek diberikan intervensi pada kelompok eksperimen

$X$ : Intervensi konseling kelompok realita pada kelompok eksperimen

O2 : Post-test setelah subjek diberikan intervensi pada kelompok eksperimen

R2 : Penempatan kelompok secara acak pada kelompok kontrol

O3 : Pre-test sebelum subjek diberi intervensi pada kelompok kontrol
- $\quad$ : Konseling kelompok pada kelompok tanpa teknik pada kelompok kontrol

O4 : Post-test setelah subjek diberikan intervensi pada kelompok kontrol

\section{Waktu Penelitian}

Prosedur intervensi yang diberikan kepada kelompok eksperimen adalah menggunakan konseling kelompok realita. Proses konseling dilaksanakan pada enam kali pertemuan yang masing-masing pertemuan berlangsung sekitar 40 menit. Waktu penelitian ini, disajikan pada langkah-langkah sebagai berikut:

Tabel 1.

Tahap-tahap Konseling Kelompok Realita

\begin{tabular}{|c|c|c|c|}
\hline Pertemuan & Tahapan & Kegiatan & Keterangan \\
\hline I & Tahap Awal & $\begin{array}{l}\text { Konselor menunjukkan keterlibatan dengan } \\
\text { konseli (Be Friend) } \\
\text { - Berkenalan } \\
\text { - Ice Breaking } \\
\text { - Menjelaskan proses berlangsungnya konseling } \\
\text { kelompok } \\
\text { - Meminta kesediaan konseli mengikuti kegiatan } \\
\text { - } \text { Menseling kelompok realita } \\
\text { Menetapkan tujuan konseling kelompok }\end{array}$ & $\begin{array}{l}\text { Konselor bersikap: } \\
\text { - } \text { Perilaku attending } \\
\text { - Otentik, hangat, menaruh } \\
\text { perhatian terhadap } \\
\text { hubungan yang sedang } \\
\text { dibangun } \\
\text { - } \text { Bersahabat dan antusian } \\
\text { - Tidak menghakimi } \\
\text { konseli }\end{array}$ \\
\hline II & $\begin{array}{l}\text { Tahap } \\
\text { Kegiatan }\end{array}$ & $\begin{array}{l}\text { Fokus pada perilaku sekarang (tahap want) } \\
\text { - Menanyakan masalah yang dihadapi siswa } \\
\text { disekolah berkenaan dengan kedisiplinan } \\
\text { siswa } \\
\text { - Fokus pada perilaku saat ini yang kurang } \\
\text { disiplin }\end{array}$ & \\
\hline III & & $\begin{array}{l}\text { Mengeksplorasikan total behavior konseli (tahap } \\
\text { doing and direction) } \\
\text { - Mengeksplorasikan tentang total behavior } \\
\text { konseli } \\
\text { - Konselor menanyakan kepada klien apa yang } \\
\text { sudah diperbuat untuk mengurangi perilaku } \\
\text { tidak disiplin }\end{array}$ & $\begin{array}{l}\text { Fungsi konselor tidak } \\
\text { untuk menilai benar salah } \\
\text { perilaku konseli, tetapi } \\
\text { membimbing konseli untuk } \\
\text { menilai perilakunya saat } \\
\text { ini. }\end{array}$ \\
\hline IV & & $\begin{array}{l}\text { Konseli menilai diri sendiri atau evaluasi (tahap } \\
\text { evaluation) } \\
\text { - Konselor mengajak klien untuk mengevaluasi } \\
\text { perilaku mereka yang indisiplin belajar, } \\
\text { bertanggung jawab atau tidak, perilakunya } \\
\text { merugikan diri sendiri atau tidak. }\end{array}$ & $\begin{array}{l}\text { Konselor tidak untuk } \\
\text { menilai benar atau salah } \\
\text { perilaku konseli, teta- } \\
\text { pi membimbing konseli } \\
\text { untukmenilai perilkau saat } \\
\text { ini. }\end{array}$ \\
\hline $\mathrm{V}$ & & $\begin{array}{l}\text { Merencanakan tindakan yang bertanggung jawab } \\
\text { (tahap planning) } \\
\text { - Membuat rencana tindakan. atas perilakunya } \\
\text { yang tidak disiplin, membantu mereka } \\
\text { membuat perencanaan untuk mengubah } \\
\text { perilaku mereka lebih disiplin belajar dan } \\
\text { bertanggung jawab. }\end{array}$ & $\begin{array}{l}\text { Konselor mendorong kon- } \\
\text { seli untuk merealisasikan } \\
\text { rencana yang telah disusun } \\
\text { dalam jangka waktu yang } \\
\text { telah ditentukan. }\end{array}$ \\
\hline VI & $\begin{array}{l}\text { Tahap } \\
\text { Pengakhiran }\end{array}$ & Evaluasi tindak lanjut & $\begin{array}{l}\text { Konselor dan konseli men- } \\
\text { gevaluasi kegiatan konsel- } \\
\text { ing kelompok yang sudah } \\
\text { dilaksanakan }\end{array}$ \\
\hline
\end{tabular}




\section{Populasi dan Sampel}

Populasi dalam penelitian ini, jumlah siswa kelas 6 MI adalah 63 siswa. Namun berdasarkan wawancara dan data yang diperoleh dari guru BK, siswa yang memiliki kedisiplinan belajar rendah adalah kelas $6 \mathrm{~B}$ yang siswanya berjumlah 25 siswa. Berikut tabel jumlah populasi secara keseluruhan kelas 6.

Tabel 2.

Jumlah Populasi Penelitian

\begin{tabular}{ccc}
\hline Kelas & Jenis Kelamin & Jumlah \\
\hline Kelas 6 B & Perempuan & 25 \\
& Laki-laki & 0 \\
\hline
\end{tabular}

Berdasarkan data yang diperoleh dari hasil angket kedisiplinan belajar berdasarkan teori Hurlock (1978) teridentifikasi 8 orang yang memiliki skor kedisipilinan rendah yang dibagi pada kelompok eksperimen dan kelompok kontrol dengan menggunakan teknik purposive sample (sampel bertujuan), yaitu sampel yang diambil disesuaikan dengan tujuan tertentu dari penelitian. Secara visual, kerangka kerja penelitian, diilustrasikan dalam gambar sebagai berikut:

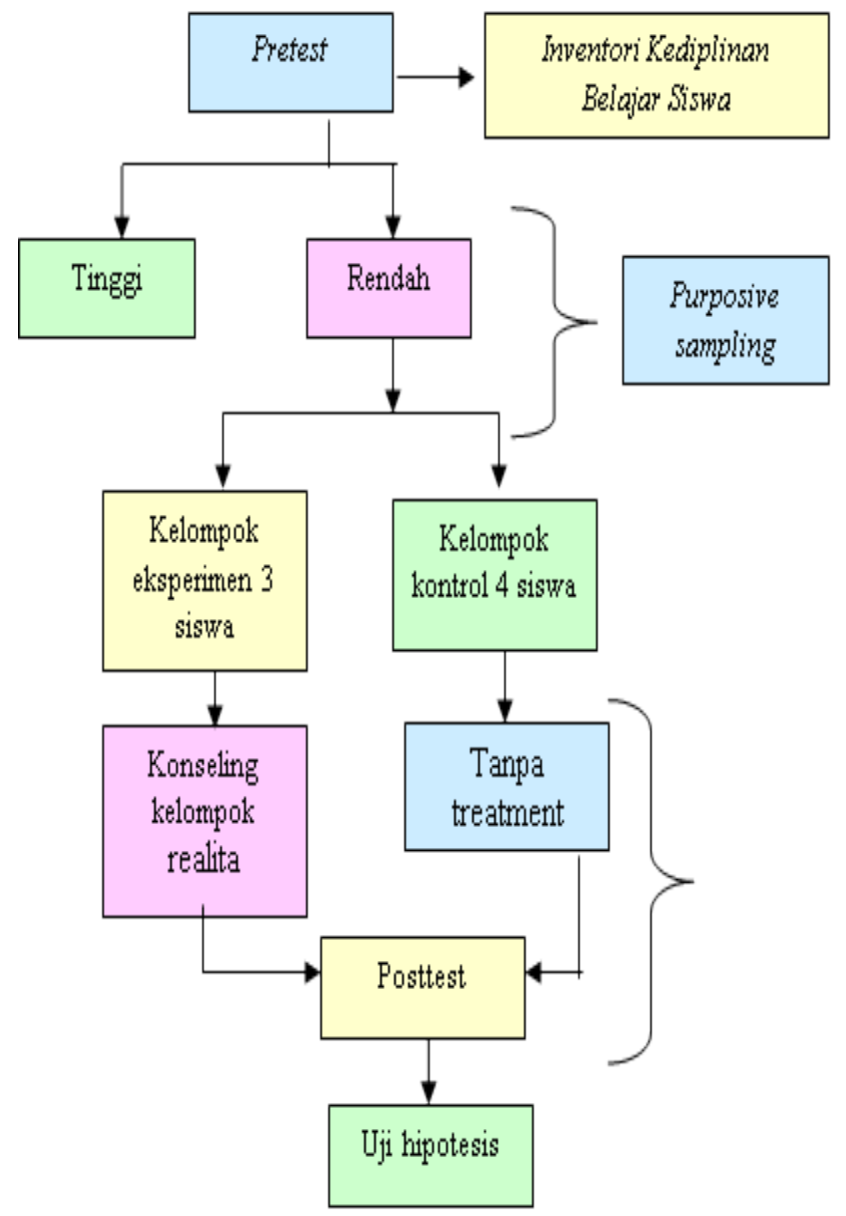

Gambar 3. Kerangka Rancangan Penelitian

(Diadaptasi dari: Habsy, 2018)
Hasil penjaringan dari inventori untuk kelompok eksperimen dan kelompok kontrol dapat dilihat pada tabel 3 di bawah ini:

Tabel 3.

Rekapitulasi Hasil Skor Pre Test Kelompok Eksperimen dan Kelompok Kontrol

\begin{tabular}{llllll}
\hline No & $\begin{array}{c}\text { Kelompok } \\
\text { Kontrol }\end{array}$ & & No & $\begin{array}{l}\text { Kelompok } \\
\text { Eksperimen }\end{array}$ \\
\hline 1 & ANR & 118 & 1 & PV & 127 \\
2 & RA & 106 & 2 & LH & 121 \\
3 & NW & 119 & 3 & SSA & 128 \\
4 & SRC & 125 & 4 & AME & 109 \\
\hline
\end{tabular}

\section{Prosedur Pengumpulan Data}

Adapun dalam menyusun instrumen pengumpul data dalam penelitian ini dengan menggunakan angket berdasarkan teori Hurrlock (1978) yang terdiri atas indikator-indikator yaitu (1) patuh dan taat terhadap tata tertib belajar di sekolah, (2) persiapan belajar, (3) perhatian terhadap kegiatan pembelajaran, (4) dan menyelesaikan tugas pada waktunya. Adapun kisi-kisi angket yang berkaitan dengan kediplinan belajar siswa berdasarkan teori Hurlock dapat dilihat pada tabel 4 berikut ini:

Tabel 4.

Kisi-Kisi Angket Variabel Kedisiplinan Belajar Siswa

\begin{tabular}{|c|c|c|c|c|}
\hline $\begin{array}{l}\text { Vari- } \\
\text { abel }\end{array}$ & Aspek & Indikator & $\begin{array}{c}\text { No. } \\
\text { Item } \\
(+)\end{array}$ & $(-)$ \\
\hline \multirow{5}{*}{ 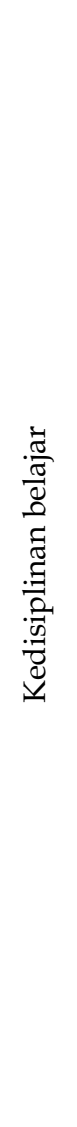 } & $\begin{array}{l}\text { 1. Patuh } \\
\text { dan taat } \\
\text { terhadap } \\
\text { tata tertib } \\
\text { belajar di } \\
\text { sekolah }\end{array}$ & $\begin{array}{l}\text { a. Datang dan pulang } \\
\text { tepat waktu } \\
\text { b. Tertib berpakaian } \\
\text { c. Hadir pada saat salam } \\
\text { pagi dan salam siang } \\
\text { d. Menjaga kebersihan } \\
\text { sekolah }\end{array}$ & 4,5 & 32,33 \\
\hline & & & 6,7 & 8,9 \\
\hline & $\begin{array}{l}\text { 2. Persiapan } \\
\text { belajar }\end{array}$ & $\begin{array}{l}\text { a. Kehadiran saat bela- } \\
\text { jar dalam kelas } \\
\text { b. Membawa buku pe- } \\
\text { lajaran sesuai jadwal } \\
\text { pelajaran } \\
\text { c. Mengikuti kegiatan } \\
\text { Tadarus dan Sholat } \\
\text { Dhuha }\end{array}$ & $\begin{array}{c}10,11 \\
31\end{array}$ & $\begin{array}{l}34 \\
12\end{array}$ \\
\hline & $\begin{array}{l}\text { 3. Perhatian } \\
\text { terhadap } \\
\text { kegiatan } \\
\text { pembela- } \\
\text { jaran }\end{array}$ & $\begin{array}{l}\text { a. Tertib saat belajar } \\
\text { dikelas } \\
\text { b. Penggunaan fasilitas } \\
\text { c. Tidak keluar kelas } \\
\text { pada saat jam pela- } \\
\text { jaran }\end{array}$ & $\begin{array}{l}16 \\
35\end{array}$ & $\begin{array}{c}17,18 \\
19 \\
36\end{array}$ \\
\hline & $\begin{array}{l}\text { 4. Menyele- } \\
\text { saikan tu- } \\
\text { gas pada } \\
\text { waktunya }\end{array}$ & $\begin{array}{l}\text { a. Ketaatan mengerja- } \\
\text { kan tugas } \\
\text { b. Mengerjakan soal } \\
\text { ulangan harian } \\
\text { c. Tidakmenyontek saat } \\
\text { mengerjakan tugas } \\
\text { d. Tidak meny uruh } \\
\text { teman untuk menger- } \\
\text { jakan tugas }\end{array}$ & $\begin{array}{l}22, \\
23,24\end{array}$ & \\
\hline
\end{tabular}




\section{Analisis Data}

Dalam mengadakan penelitian, maka untuk memperoleh suatu data diadakan penelitian sehingga yang dijadikan obyek penelitian itu terlihat jelas dan sesuai dengan tujuan penelitian. Dengan demikian metode analisis data yang digunakan dalam penelitian ini menggunakan metode analisis data statistik berwujud angka atau bersifat kuantitatif.

Untuk mengidentifikasi keefektifan konseling kelompok realita untuk meningkatkan kedisiplinan siswa, maka dalam penelitian ini penulis menggunakan analisis data statistik dengan teknik T-test (Sutrisno, 2000) yaitu dengan menggunakan rumus:

Keterangan:

$$
\frac{M_{e-M_{e}}}{\sqrt{\frac{\sum b^{2}}{N(N-1)}}}
$$

$$
\begin{array}{lll}
\mathrm{M}_{\mathrm{k}} \text { dan } \mathrm{M}_{\mathrm{e}}: & \begin{array}{l}
\text { Masing-masing adalah mean dari } \\
\text { kelompok kontrol dan mean dari } \\
\end{array} \\
& \text { kelompok eksperimen } \\
\Sigma \mathrm{b}^{2} & : \begin{array}{l}
\text { Jumlah deviasi dari mean perbe- } \\
\text { daan }
\end{array} \\
\mathrm{N} & : \text { Jumlah subyek }
\end{array}
$$

Data yang lebih akurat dan efisien dalam perhitungannya, maka perhitungan analisis data akan dikerjakan dengan menggunakan program SPSS 20 For Windows. Dalam penelitian ini, peneliti mengajukan dua hipotesis yaitu hipotesa kerja $\left(\mathrm{H}_{\mathrm{a}}\right)$ dan hipotesa nihil $\left(\mathrm{H}_{0}\right)$. Kedua hipotesa tersebut adalah sebagai berikut:

1. $\mathrm{H}_{\mathrm{a}}$ : Pelaksanaan layanan konseling kelompok realita efektif dalam meningkatkan kedisiplinan siswa kelas 6B MI

2. $\mathrm{H}_{0}$ : Pelaksanaan layanan konseling kelompok realita tidak efektif dalam meningkatkan kedisiplinan siswa kelas 6B MI

Ketentuan penerimaan dan penolakan hipotesis di atas adalah sebagai berikut:

- Terima $\mathrm{H}_{0}$, jika $\mathrm{t}_{\text {hitung }}<\mathrm{t}_{\text {tabel; }}$ dengan kata lain $\mathrm{H}_{\mathrm{a}}$ ditolak

- Tolak $\mathrm{H}_{0,}$ jika $t_{\text {hitung }}>\mathrm{t}_{\text {tabel; }}$ dengan kata lain $\mathrm{H}_{\mathrm{a}}$ diterima

\section{HASIL DAN PEMBAHASAN}

\section{Hasil}

Setelah kelompok eksperimen diberikan layanan konseling kelompok sebanyak 6 kali pertemuan, kedua kelompok dikumpulkan kemudian diberi posttest. Hal ini dimaksudkan untuk membandingkan ada tidaknya perbedaan kedisiplinan belajar sebelum dan sesudah diberikan layanan konseling kelompok realita. Selain itu, pemberian posttest juga dimaksudkan untuk membedakan hasil antara kelompok kontrol dan kelompok eksperimen. Posttest dilkukan dengan memberikan angket kedisiplinan belajar lagi kepada kedua kelompok yang terdiri dari 36 item. Hasil posttest tersebut dapat dilihat dalam tabel berikut ini:

Tabel 5 .

Hasil Posttest Kedisiplinan Belajar Antara Kelompok Kontrol dan Eksperimen

\begin{tabular}{clllll}
\hline No & $\begin{array}{c}\text { Kelompok } \\
\text { Kontrol }\end{array}$ & & No & $\begin{array}{l}\text { Kelompok } \\
\text { Eksperimen }\end{array}$ \\
\hline 1 & ANR & 135 & 1 & PV & 151 \\
2 & RA & 146 & 2 & LH & 152 \\
3 & NW & 140 & 3 & SSA & 165 \\
4 & SRC & 143 & 4 & AME & 164 \\
\hline
\end{tabular}

Setelah semua data telah terkumpul sesuai dengan metode yang telah digunakan, maka langkah selanjutnya adalah menganalisis data. Analisis data digunakan untuk mengetahui hasil akhir dari penelitian yang dilakukan dengan cermat dan teliti. Dalam penelitian ini yang digunakan untuk menganalisis data adalah menggunakan uji T-Test.

\begin{tabular}{|c|c|c|c|c|c|c|c|}
\hline \multicolumn{4}{|c|}{ Kelompok Kontrol } & \multicolumn{4}{|c|}{ Kelompok Eksperimen } \\
\hline Nama & $\begin{array}{c}\text { Pre- } \\
t \text { es } t \\
\left(X_{1}\right)\end{array}$ & $\begin{array}{c}\text { Post- } \\
t e s t \\
\left(X_{2}\right)\end{array}$ & $\begin{array}{c}\text { Beda } \\
(X)\end{array}$ & Nama & $\begin{array}{c}\text { Pre- } \\
t \text { es } t \\
\left(X_{1}\right)\end{array}$ & $\begin{array}{c}\text { Post- } \\
\text { tes } t \\
\left(X_{2}\right)\end{array}$ & $\begin{array}{c}\text { Be d a } \\
(X)\end{array}$ \\
\hline ANR & 118 & 135 & 17 & PV & 127 & 151 & 24 \\
\hline RA & 106 & 146 & 40 & LH & 121 & 152 & 31 \\
\hline NW & 119 & 140 & 21 & SSA & 128 & 165 & 32 \\
\hline SRC & 125 & 143 & 18 & AME & 109 & 164 & 55 \\
\hline
\end{tabular}
Data hasil pretest dan posttest antara kelompok kontrol dan kelompok eksperimen dapat dilihat pada tabel berikut ini:

Tabel 6.

Hasil pretest dan posttest antara Kelompok Kontrol dan kelompok Eksperimen

Perbedaan skor pretest dan posttest antara kelompok kontrol dan kelompok eksperimen secara jelas ditunjukkan dalam diagram berikut:

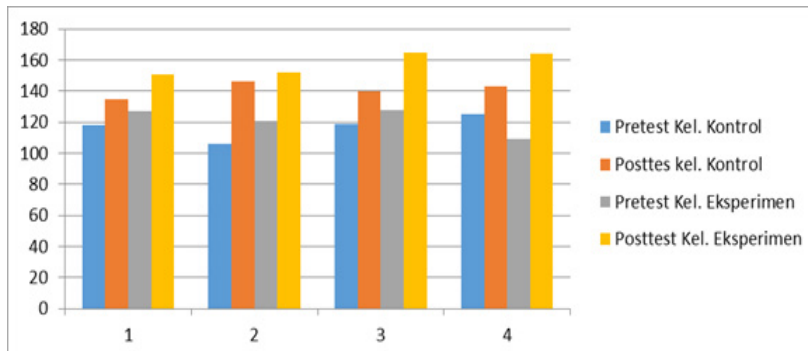

Gambar 4. Perbedaan skor pretest dan posttest antara kelompok eksperimen dan kontrol 
Selanjutnya data tersebut setelah diolah menggunakan program SPSS 20,00 for windows dapat diamati pada tabel Group Statistics berikut ini:

Tabel 7.

Group Statistics

\begin{tabular}{|c|c|c|c|c|c|}
\hline & $\begin{array}{c}\text { Jenis } \\
\text { Kelompok }\end{array}$ & $\mathbf{N}$ & Mean & $\begin{array}{c}\text { Std. } \\
\text { Deviation }\end{array}$ & $\begin{array}{c}\text { Std. } \\
\text { Error } \\
\text { Mean }\end{array}$ \\
\hline 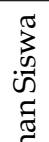 & Eksperimen & 4 & 155,50 & 6,455 & 3,227 \\
\hline : & Kontrol & 4 & 144,00 & 4,690 & 2,345 \\
\hline
\end{tabular}

Dari tabel 7 dapat diketahui mean (rata-rata) dari kelompok kontrol adalah 144,00, sedangkan mean kelompok eksperimen adalah 155,50. Standar deviasi untuk kelompok kontrol adalah 4,689 sedangkan Standar Deviasi kelompok eksperimen adalah 6,455. Standar Error untuk mean kelompok kontrol adalah 2,345 dan Standar Error untuk mean kelompok eksperimen adalah 3, 227.

Dari data tersebut, selanjutnya dilakukan pengujian t-tes (Independen Sample t-test) menggunakan program SPSS 20.00 window. Hasil pengujian tersebut dapat diamati pada tabel 8 berikut ini:

Tabel 8.

Ringkasan Hasil Uji T-test Kelompok Kontrol dan kelompok Eksperimen Independen Samples Test

\begin{tabular}{|c|c|c|c|c|c|c|c|}
\hline \multicolumn{2}{|c|}{$\begin{array}{l}\text { Levene's Test } \\
\text { for Equality } \\
\text { of Variances }\end{array}$} & \multicolumn{6}{|c|}{ t-test for Equality of Means } \\
\hline \multirow[t]{2}{*}{$\mathrm{F}$} & \multirow[t]{2}{*}{ Sig. } & \multirow[t]{2}{*}{$\mathrm{T}$} & \multirow[t]{2}{*}{$\begin{array}{l}\text { Sig. } \\
\text { (2-tailed) }\end{array}$} & \multirow[t]{2}{*}{$\begin{array}{l}\text { Mean } \\
\text { Difference }\end{array}$} & \multirow[t]{2}{*}{$\begin{array}{l}\text { Std. Error } \\
\text { Difference }\end{array}$} & \multicolumn{2}{|c|}{$\begin{array}{l}95 \% \text { Confidence } \\
\text { Interval of the } \\
\text { Difference }\end{array}$} \\
\hline & & & & & & Lower & Upper \\
\hline ,362 & ,569 & $3,634 \quad 6$ & 011 & 14,500 & 3,990 & 4,738 & 24,262 \\
\hline & & $3,634 \quad 5,477$ & 013 & 14,500 & 3,990 & 4,508 & 24,492 \\
\hline
\end{tabular}

Dari perhitungan levene's test dapat dilihat angka signifikan sebesar 0,569 lebih besar dari 0,05 yang berarti bahwa hipotesis nihil diterima sehingga dapat disimpulkan bahwa varians populasi identik/ homogen. Oleh karena hipotesis yang dipakai adalah bahwa kedua varians populasi identik/homogen, maka yang dijadikan pedoman untuk analisis lebih lanjut adalah hasil yang terdapat pda baris Equal variaces ussumed.

Hasil analisis Uji-T yang juga terdapat pada tabel 5, pada tabel tersebut diketahui $t_{\text {hitung }}$ adalah sebesar 3,634 dan angka propabilitas (Sig. (2-tailed) adalah 0,11 dengan $\mathrm{df}=6$. Selanjtnya harga tersebut dibandingkan dengan harga $t_{\text {tabel }}$ pada taraf signifikan $5 \%$ uji dua pihak dengan $\mathrm{df}=6$, sehingga diketahui harga $t_{\text {tabel }}$ adalah $(2,44691)$. Karena harga $t_{\text {hitung }}(3,634)$ lebih besar dari harga $t_{\text {tabel }}(2,44691)$.atau 3,3634 < 2,44691 dan nilai probalilitas yang diperoleh adalah 0,11 lebih kecil dari 0.005, maka dapat dikatakan bahwa kedisiplinan belajar siswa sebelum dan sesudah dilaksanakan konseling kelompok realita pada kelompok eksperimen terdapat perbedaan yang signifikan. Dengan kata lain, konseling kelompok realita efektif untuk meningkatkan kedisiplinan belajar siswa kelas 6B MI.

Untuk mengetahui diterima atau tidaknya hipotesis yang diujikan dalam penelitian yang disajikan dalam penelitian ini maka dilakukan pengujian hipotesis. Hipotesis dalam penelitian ini adalah:

a. $\mathrm{H}_{\mathrm{a}}$ : Pelaksanaan layanan konseling kelompok realita efektif dalam meningkatkan kedisiplinan belajar siswa kelas 6B MI

b. $\mathrm{H}_{0}$ : Pelaksanaan layanan konseling kelompok realita tidak efeketif dalam meningkatkan kedisiplinan belajar siswa kelas 6B MI

Adapun kriteria pengujian hipotesis adalah sebagai berikut:

- Terima $\mathrm{H}_{0^{\prime}}$ jika thitung, $\mathrm{t}_{\text {tabel }}$; dengan kata lain $\mathrm{H}_{\mathrm{a}}$ ditolak

- Tolak $\mathrm{H}_{0^{\prime}}$ jika thitung. $\mathrm{t}_{\text {tabel }}$; dengan kata lain $\mathrm{H}_{\mathrm{a}}$ diterima 
Dari perhitungan SPSS 20.00 for Windows diketahui $t_{\text {hitung }}$ adalah sebesar 3,634 dan angka probabilitas (Sig. (2-tailed) adalah 0,11 dengan $\mathrm{df}=$ 6. Selanjutnya harga tersebut dibandingkan dengan harga $t_{\text {tabel }}$ pada taraf signifikan $5 \%$ uji dua pihak dengan $\mathrm{df}=6$, sehingga diketahui harga $t_{\text {tabel }}$ adalah 2,44691 lebih besar dari harga $t_{\text {tabel }}(2,44691)$ atau 3,634 $-2,44691$ dan nilai probabilitas yang diperoleh adalah 0,11 lebih kecil dari 0,005. Dengan demikian dalam penelitian ini dapat disimpulkan bahwa hipotesis kerja $\left(\mathrm{H}_{\mathrm{a}}\right)$ yang menyatakan "Pelaksanaa layanan konseling kelompok realita efektif untuk meningkatkan kedisiplinan belajar siswa kelas 6B MI" diterima. Sedangkan hipotesis nihil $\left(\mathrm{H}_{0}\right)$ yang menyatakan: "Pelaksanaan layanan konseling kelompok realita tidak efektif untuk meningkatkan kedisiplinana belajar siswa kelas 6B MI" ditolak. Hal ini terjadi karena harga $\mathrm{t}_{\text {hitung }} 3,634>2,44691$ pada taraf signifikan $a=0.05(5 \%)$.

\section{Pembahasan}

Pemberian layanan konseling kelompok realita merupakan salah satu langkah untuk meningkatkan kedisiplinan belajar siswa di sekolah. Dalam konseling kelompok realita siswa diajak untuk mengevaluasi perilakunya selama ini dan mengarahkan perilakunya ke arah yang lebih baik. Hal ini yang diterapkan dalam meningkatkan kedisiplinan siswa.

Gambaran tentang efektifitas layanan konseling kelompok realita untuk meningkatkan kedisiplinan diri siswa pada penelitian ini dapat dilihat dari diterimanya hipotesis kerja $\left(\mathrm{H}_{\mathrm{a}}\right)$ yang menyatakan bahwa 'Pelaksanaan layanan konseling kelompok realita efektif untuk meningkatkan kedisiplinan belajar siswa kelas 6B MI" diterima. Sedangkan hipotesis nihil $\left(\mathrm{H}_{0}\right)$ yang menyatakan "Pelaksanaan konseling kelompok realita tidak efektif untuk menngkatkan kedisiplinan belajar siswa kelas 6B MI" ditolak.

Secara garis besar, tahapan-tahapan yang dilakukan peneliti dalam pemberian layanan konseling kelompok realita meliputi:

a. Tahap pembentukan

Pada pertemuan pertama, kegiatan yang diakukan adalah siswa dan konselor saling berkenalan untuk pengakraban dan pembentukan hubungan satu sama lain. Tujuan umum dari tahap ini adalah saling mengenal antar anggota dan konselor. Materi yang disajikan hanyalah perkenalan, permainan sebagai pengakraban, penyampaian azas-azas konseling kelompok, dan kontak waktu pelaksanaan konseling yang dilaksanakan. Ice Breaking yang digunakan adalah "Siapa Dia?" b. Tahap kegiatan

Pada pertemuan kedua, siswa diajak berdiskusi pada keinginan dan perilakunya sekarang, tahap inidalam konseling kelompok realita dinamakan tahap eksplorasi wants. Dalam pertemuan ini siswa diberi contoh-contoh kasus kedisiplinan belajar rendah. Contoh kasus yang diberikan kepada siswa dalam bentuk cerita dan gambar. Selanjutnya siswa dan konselor mendiskusikan kasus tersebut. Hasil yang ingin dicapai siswa dapat mengetahui, memahami, dan mendiskusikan contoh kedisiplinan belajar rendah dan bisa mengubah perilaku yang awalnya mempunyai kedisiplinan belajar rendah menjadi lebih baik.

Pertemuan ketiga, proses konseling kelompok masuk pada tahap mengeksplorasi total behavior konseli (tahap doing and direction). Konselor menunjukkan kepada siswa contoh cerita tentang perilaku disiplin yang bisa membuahkan kesuksesan dikemudian harinya, untuk mengekplorasi total behavior konseli. Konseli diajak oleh konselor untuk mengidentifikasi dan mendiskusikan cerita tersebut yang berisi tentang motivasi bahwa jika melakukan suatu pekerjaan dengan disiplin maka akan meraih sukses pada kemudian hari.

Pertemuan keempat masuk pada konseli menilai diri sendiri atau evaluasi (tahap evaluation). Dalam pertemuan ini konselor mengajak konseli untuk menilai dirinya sendiri dan perilakunya. Pertemuan ini bertujuan agar konseli dapat menilai baik atau tidaknya perilaku yang selama ini dilakukan.

Pertemuan kelima masuk dalam tahap merencanakan tindakan yang bertanggung jawab (tahap planning) dan membuat komitmen. Dalam tahap ini konselor mengajak konseli untuk merencanakan tindakan yang bertanggung jawab dan membuat komitmen untuk mengubah perilakunya yang kedisiplinan belajar rendah. Tujuan yang ingin dicapai dalam pertemuan kelima ini adalah agar konseli mampu membuat perencanaan sikap yang bertanggung jawab dan mampu mengarahkan perilakunya dengan lebih baik.

\section{c. Tahap pengakhiran}

Pertemuan keenam adalah pertemuan terakhir dari rangkaian proses konseling kelompok. Dalam pertemuan ini konselor dan konseli mengevaluasi seluruh proses yang telah dilalui dalam beberapa kali pelaksanaan 
konseling kelompok. Untuk lebih jelasnya tentang pelaksanaan pemberian layanan konseling kelompok realita dapat dilihat pada lampiran rancangan kegiatan konseling kelompok.

Dalam pelaksanaan konseling kelompok realita tersebut, ditemukan beberapa perubahan sikap dari konseli. PV (Konseli 1) skor pretest kedisiplinan belajar siswa yang diperoleh PV adalah 127 termasuk dalam kategori sedang. PV mempunyai masalah kedisiplinan belajar siswa adalah dia sering tidak masuk sekolah, sebenarnya dia adalah anak yang pandai tetapi dia sering membolos. Hal itu dikarenakan dia memiliki semangat belajar yang kurang, dia lebih suka dirumah daripada harus kesekolah. Karena hal itu nilai pelajarannya banyak yang menurun dan banyak pelajaran yang tertinggal.

Selama konseling berlangsung, banyak motivasi yang dia dapat. PV dia lebih berani mengungkapkan masalah yang ada dalam dirinya. Dia juga menyadari bahwa yang dilakukannya selama ini salah. Selain itu dia juga berkomitmen untuk lebih giat lagi belajar. Setelah mengikuti konseling kelompok 6 kali PV mendapatkan skor post-test sebesar 151 tinggi.

LH (Konseli II) skor pretest kedisiplinan belajar siswa yang diperoleh LH adalah 121 yang termasuk kategori sedang. LH mempunyai masalah sering terlambat masuk sekolah. Karena dia sering bangun kesiangan. Pada malam harinya dia sering begadang karena melihat acara televisi kesukaannya hingga larut malam. Dan di pagi harinya dia bangun kesiangan.

Dalam proses konseling LH menjadi tahu bahwa yang selama ini dilakukannya adalah salah. Hal itu membuatnya terlambat berangkat sekolah dan mengganggu konsntrasi saat belajar dikelas karena waktu istirahatnya yang kurang. Setelah mengikuti konseling kelompok realita sealam 6 kali, LH mendapatkan skor posttest sebesar 152 yang termasuk kategori tinggi.

SSA (Konseli III) skor pretest kedisiplinan belajar siswa yang diperolehnya adalah 128 yang termasuk dalam kategori sedang. Masalah kedisiplinan belajar siswa SSA adalah dia sering tidak mengerjakan tugas sekolah dan sering menyontek pada saat ulangan harian. Selama dirumah dia tidak belajar melainkan pergi untuk bermain. Dia juga jarang sekali membawa buku pelajaran. Hal ini membuat nilai pelajarannya sangat buruk.

Dalam proses konseling kelompok realita, SSA sangat antusias dia mempunyai semngat baru dan termotivasi untuk lebih giat belajar lagi. Dan dia juga menyadari bahwa hal yang dilakukannya sangat tidak menguntungkan bagi dirinya. Setelah mengikuti konseling kelompok realita selama 6 kali, hasil posttest SSA 165 yang termasuk dalam kategori tinggi.

AME (Konseli IV) perolehan skor pre-test AME adalah 109 yang termasuk dalam kategori sedang. masalah kedisiplinan belajar siswa yang dialaminya adalah dia sering gaduh ketika jam pelajaran, sering menjahili teman-temannya hingga menangis. Perilakunya yang seperti ini juga tidak disenangi teman-temannya. Pada dasarnya AME adalah anak yang baik, namun dia tidak tahu bagaimana caranya berteman dengan sesama temannya.

Saat mengikuti kegiatan konseling kelompok, AME merasa dirinya sangat bersalah terhadap perbuatannya tidak seharusnya dia melakukan hal itu kepada temann-temannya. Dan dia mendapatkan banyak pengetahuan bagaimana cara berteman yang baik. Setelah mengikuti kegiatan konseling kelompok skor posttest AME adalah 164 yang termasuk dalam kategori tinggi.

Dari hasil penelitian ini dapat diketahui bahwa konseling kelompok realita efektif dalam meningkatkan kedisiplinan belajar siswa. Dengan hasil penelitian ini dapat diimplementasikan dalam kegiatan konseling di sekolah, antara lain, sebagai berikut:

1. Konseling kelompok realita dapat digunakan untuk mengidentifikasi tinggi atau rendahnya dan meningkatkan kedisiplinan belajar siswa MI.

2. Dengan adanya penelitian ini, hasilnya bisa digunakan untuk acuan guru pembimbing dalam memberikan layanan konseling kelompok realita untuk membantu siswa menyelesaikan masalahnya.

\section{PENUTUP}

\section{Kesimpulan}

Berdasarkan hasil penelitian yang diperoleh sebagaimana tercantum pada bab sebelumnya, maka dapat disimpulkan bahwa konseling kelompok realita efektif dalam meningkatkan kedisiplinan siswa. Hal inidapat diketahui dari perhitungan SPSS 20.00 for Windows diketahui $t_{\text {hitung }}$ adalah sebesar 3,634 dan angka (Sig. (2-tailed) adalah 0,11 dengan $\mathrm{df}=6$. Selanjutnya harga tersebut dibandingkan dengan harga $t_{\text {tabel }}$ pada taraf signifikan $5 \%$ uji dua pihak dengan $\mathrm{df}=6$, sehingga diketahui harga $t_{\text {tabel }}$ adalah 2, 4461. Karena harga $t_{\text {hitung }}(3,634)$ atau 3, 634 $>$ 2,4461 dan nilai probabilitas yang diperoleh adalah oleh 0,11 lebih kecil dari 0,005. Dengan demikian, dalam penelitian ini dapat disimpulkan bahwa pelaksanaan konseling kelompok realita efektif untuk 
meningkatkan kedisiplinan belajar siswa kelas 6B MI Semesta Kedungmaling Mojokerto.

\section{Saran}

Berdasarkan hasil penelitian disampaikan saran, sebagai berikut:

1. Bagi Guru Bimbingan dan Konseling dapat menerapkan layanan konseling kelompok ralita sebagai alternatif untuk meningkatkan kedisiplinan siswa

2. Bagi Peneliti selanjutnya, penelitian ini menggunakan pendekatan konseling kelompok realita dengan teknik metafora dan diskusi kualita, maka peneliti selanjutnya dapat menggunakan teknik lain yang relevan.

\section{DAFTAR PUSTAKA}

Arisana, A. L., \& Ismani, I. (2012). Pengaruh Kedisiplinan Siswa dan Persepsi Siswa tentang Kualitas Mengajar Guru terhadap Prestasi Belajar Akuntansi Siswa Kelas XI IPS MAN Yogyakarta II Tahun Ajaran 2011/2012. Jurnal Pendidikan Akuntansi Indonesia, 10(2), 22-42. DOI: 10.21831/jpai.v10i2.911.

Gunawan, L. N. (2017). Hubungan antara kontrol diri dan penyesuaian diri dengan kedisiplinan siswa MTS Sulaiman Yasin Samarinda. PSIKOBORNEO: Jurnal Ilmiah Psikologi, 5, 1, 104-117. Diakses melalui http://ejournal.psikologi. fisip-unmul.ac.id/site/? $\mathrm{p}=1252$.

Habsy, B. A., Hidayah, N., Lasan, B. B., \& Muslihati, M. (2017, September). A literature review of indonesian life concept linuwih based on the teachings of adiluhung Raden Mas Panji Sosrokartono. In 3rd International Conference on Education and Training (ICET 2017). Atlantis Press.

Habsy, B. A. (2017a). Model konseling kelompok cognitive behavior untuk meningkatkan self esteem siswa SMK. Perspektif Ilmu Pendidikan, 31(1), 21-35. doi: https://doi.org/10.21009/PIP.311.4.

Habsy, B. A. (2017b). Filosofi ilmu bimbingan dan konseling Indonesia. Jurnal Pendidikan (Teori dan Praktik), 2(1), 1-11. doi: http://dx.doi. org/10.26740/jp.v2n1.p1-11.

Habsy, B. A. (2017c). Seni memehami penelitian kualitatif dalam bimbingan dan konseling: Studi literatur. Jurnal Konseling Andi Matappa, 1(2), 90-100. doi: http://dx.doi.org/10.31100/ jurkam.v1i2.56.

Habsy, B. A. (2018). Model Bimbingan Kelompok PPPM Untuk Mengembangkan Pikiran Rasional Korban Bullying Siswa SMK Etnis Jawa. Jurnal Pendidikan (Teori dan Praktik), 2(2), 91-99. doi: http://dx.doi.org/10.26740/jp.v2n2.p91-99.

Hardiansyah, Eko. (2013). Konseling Kelompok Dengan Choice Theory Untuk Meningkatkan Motivasi Berprestasi Siswa. Psikologia: Jurnal Psikologi, 2 (1), 9-13. DOI: 10.21070/psikologia. v2i1.122.

Harlinawati, F. D. (2016). Penerapan Konseling Kelompok Realita dengan Teknik WDEP Untuk Meningkatkan Kedisiplinan Belajar Siswa Kelas VII SMP Negeri 1 Semen Kabupaten Kediri Tahun Pelajaran 2015/2016. Skripsi Tidak Diterbitkan. Kediri: Fakultas Keguruan dan Ilmu Pendidikan (FKIP) Universitas Nusantara Persatuan Guru Republik Indonesia. Diakses melalui http://simki.unpkediri.ac.id/mahasiswa/file_artikel/2016/12.1.01.01.0104.pdf

Hurlock, E. B. (1978). Child growth and development. Tata McGraw-Hill Education.

Islam, D. J. P. (2001). Departemen Agama RI. Metodologi Pendidikan Agama Islam. Jakarta.

Isnaini, F. (2014). Strategi self-management untuk meningkatkan kedisiplinan belajar. Jurnal Penelitian Humaniora, 16 (2) 33-42. DOI: $10.23917 /$ humaniora.v16i2.1842

Manning, M. L. (2002). Havighurst's developmental tasks, young adolescents, and diversity. The Clearing House: A Journal of Educational Strategies, Issues and Ideas, 76(2), 75-78. DOI: $\underline{10.1080 / 00098650209604953}$

Rahman, D. H. (2015). Keefektifan Teknik Metafora dalam Bingkai Konseling Realitas untuk Meningkatkan Harga Diri Siswa. Jurnal Konseling Indonesia, 1(1), 47-53. DOI: 10.21067/jki.v1i1.856

Rosidah, A. (2016). Bimbingan kelompok melalui teknik problem solving untuk meningkatkan penyesuaian diri siswa terisolir. Jurnal Fokus Konseling, 2(2), 136-143. DOI: 10.26638/ jfk.217.2099.

Widodo, B. (2013). Perilaku Disiplin Siswa Ditinjau Dari Aspek Pengendalian Diri (Self Control) Dan Keterbukaan Diri (Self Disclosure) Pada Siswa SMK Wonoasri Caruban Kabupaten Madiun. Widya Warta, 37(01). Diakses melalui http://id.portalgaruda.org/?ref=browse\&$\underline{\bmod =\text { viewarticle\&article }=116801 \text {. }}$. 